\title{
Correction to: Qualitative Assessment of Geoheritage for Geotourism Promotion: a Case Study from Mehrangarh Ridge in Jodhpur City, Western Rajasthan, India
}

\author{
Mathur Saurabh ${ }^{1} \cdot$ Sharma Sudhanshu' ${ }^{1}$ Singh S. K. ${ }^{1} \cdot$ Mathur S. C. $^{2}$
}

Published online: 15 October 2021

(c) The Author(s), under exclusive licence to The European Association for Conservation of the Geological Heritage 2021

Correction to: Geoheritage (2021) 13: 80

https://doi.org/10.1007/s12371-021-00604-5

The wrong Supplementary file was originally published with this article; it has now been replaced with the correct file.

The original article has been corrected.

Supplementary Information The online version contains supplementary material available at https://doi.org/10.1007/s12371-021-00613-4.

The original article can be found online at https://doi.org/10.1007/ s12371-021-00604-5.

Mathur Saurabh

saurabh.59659@mygyanvihar.com

1 Centre for Climate Change and Water Research, Suresh

Gyan Vihar University, Jaipur, India

2 Department of Geology, J.N. Vyas University, Jodhpur, India 